THE KURUME MEDICAL JOURNAL Vol. 2, No. 3, 1955

\title{
STUDIES ON THE INFLUENCE UPON THE SUSCEPTIBILITY OF MICE TO VIRUS III REPORT

\author{
Effect of cortisone on the susceptibility of mice to virus (3)
}

\author{
YOH NAKAGAWA AND YUKISHIGE KANDA \\ Department of Bacteriology, Kurume University School \\ of Medicine, Kurume-shi, Japan
}

In the previous report (1) the present authors confirmed that relatively large dose of cortisone, when employed as a preliminary treatment, had promoted the susceptibility of mice to mouse encephalomyelitis virus. As already pointed out (2), the hypofunction of reticuloendothelial system (abbreviated R.E.S. below) following the atrophy of spleen which occured at this time was a meaning matter for the purpose of solution of mechanism of the action of cortisone and large doubts which should be solved in more details were remained upon the meaning of the susceptibility to virus. The authors had some questions that virus susceptibility increasing effect depended on a direct action of cortisone or not, how much the hypofunction of R.E.S. following the atrophy of spleen was effective as the action of cortisone, or further how its secondary influence was distinguished from the general action of cortisone.

In this report, the authors tried to make clear these doubts. And it was cleared that virus susceptibility increasing effect of cortisone was a secondary influence based on the deficiency of some factors which should be recognized as R.E.S. hormone had a close relation on the enzymic system in living bodies and that hormone played an important role in the susceptibility to virus. Further, the authors would like to explain the opinion concerning the existence of the chain of hormone between adrenocortex and R.E.S. should be added to pituitary-adrenocortical system which constitutes the foundation of inner secretory protecting mechanism.

\section{A. Effect of spleen homogenate on the susceptibility increasing effect of cortisone.}

\section{Materials and Methods}

Mouse: Healty mice of 3 or 4 week-old (weighting about $10 \mathrm{~g}$ ) were used and they were taken care so as to be maintained in the same condition as possible. 
Virus: Mouse encephalomyelitis virus (GD VII strain) used in this experiment was obtained from Dr. Rustigian of Chicago university.

Cortisone and its administration: Cortisone used in this experiment was Cortone acetate (Merck) and daily dosage of $1.0 \mathrm{mg}$ was intramuscularly administered for 2 days as a preliminary treatment. Matters that demand special attention were already described in the first report (1).

Spleen homogenate and its administration: The method preparing a spleen homogenate is same that described by Cole et al (3). Spleens of 3 week-old mice were collected and homogenated with $\mathrm{M} / 15$ phosphate buffer of $\mathrm{pH} 7.2$ in the cold so that $1 \mathrm{cc}$ of the buffer contained two spleens. And then $0.2 \mathrm{cc}$ of that was intraperitoneally injected into mice as follows; 2 times in parallel to the administration of cortisone and further 2 times not in combination with cortisone. However, the homogenate was prepared at each time of administration so as to use fresh one.

Method of inoculation of virus and the observation: $0.3 \mathrm{cc}$ of infected mouse brain emulsions diluted to $10^{-5}, 10^{-6}, 10^{-7}$ and $10^{-8}$ were intracerebrally inoculated to 5 mice of each group of dilutions respectively and the results were decided according to the $\mathrm{LD}_{50}$ of each experiment. Thus 3 groups were prepared. They were an experimental group, administered with both cortisone and spleen homogenate, a non-treated control group and another group, administered with cortisone and a buffer solution in stead of the spleen homogenate under the same condition. Other methods in the experiment are same as those previously described (1).

\section{Experimental Results}

The results are shown in Table $1 . \mathrm{LD}_{50}$ of the group treated with both cortisone and spleen homogenate was $10^{-7.5}$ and that of the other group treated with both cortisone and the buffer solution was 10-7.6. Compared $\mathrm{LD}_{50}$ of both treated groups with that of the non-treated group, $10^{-6.5}$, log. difference of $\mathrm{LD}_{50}$ were $>1.0$ and $>1.1$ respectively. Accordingly, the spleen homogenate did not show any influence upon the susceptibility increasing effect of cortisone, of course the adminstration of the buffer solution also was not affected.

\section{B. Effect of Milzsin on the susceptibility increasing effect of cortisone.}

\section{Materials and Methods}

Administration of cortisone: Daily $0.5 \mathrm{mg}$ of cortisone was intramuscularly administered for 4 days as a preliminary treatment before the inoculation of virus. 
TABLE 1

Effect of spleen homogenate on the increase of susceptibility by cortisone

\begin{tabular}{|c|c|c|c|c|c|c|}
\hline $\begin{array}{l}\text { No. } \\
\text { of } \\
\text { exp. }\end{array}$ & Treatment & $\begin{array}{l}\text { Virus } \\
\text { dilution }\end{array}$ & Result & $\begin{array}{l}\text { Incub. } \\
\text { period }\end{array}$ & $\mathrm{LD}_{50}$ & $\begin{array}{l}\text { Log. } \\
\text { diff. }\end{array}$ \\
\hline \multirow{4}{*}{1} & \multirow{4}{*}{$\begin{array}{l}\text { cortisone } \\
\text { spleen homog. }\end{array}$} & $10^{-5}$ & $5 / 5$ & 4.7 & \multirow{4}{*}{$>10^{-7.5}$} & \multirow{4}{*}{$>1.0$} \\
\hline & & $10^{-6}$ & $5 / 5$ & 5.3 & & \\
\hline & & $10^{-7}$ & $4 / 5$ & 6.6 & & \\
\hline & & $10^{-8}$ & $1 / 5$ & 7 & & \\
\hline \multirow{8}{*}{2} & \multirow{4}{*}{$\begin{array}{l}\text { cortisone } \\
\text { buffer solut. }\end{array}$} & $10^{-5}$ & $4 / 4$ & 4.5 & \multirow{4}{*}{$>10^{-7.6}$} & \multirow{4}{*}{$>1.1$} \\
\hline & & $10^{-6}$ & $5 / 5$ & 5.4 & & \\
\hline & & $10^{-7}$ & $5 / 5$ & 6.5 & & \\
\hline & & $10^{-8}$ & $1 / 5$ & 7 & & \\
\hline & \multirow{4}{*}{ control } & $10^{-5}$ & $4 / 4$ & 5.0 & \multirow{4}{*}{$10^{-6.5}$} & \\
\hline & & $10^{-6}$ & $4 / 5$ & 6.1 & & \\
\hline & & $10^{-7}$ & $1 / 5$ & 7 & & \\
\hline & & $10^{-8}$ & $0 / 5$ & & & \\
\hline
\end{tabular}

* Harmonic mean of incubation period.

Milzsin and its administration: Milzsin manufactured by Nippon Shinyaku Co. Ltd., was a protein free derivate extracted from bovine spleen at low temperature as a splenic hormone. Once a day $0.2 \mathrm{cc}$ of it was injected intraperitoneally as follows. Firstly, 2 times of injection were conducted parallel to the administration of cortisone and further 3 times of injection were conducted not in combination of cortisone. Other 2 groups to which Milzsin alone and cortisone alone were injected respectively, and another non-treated group were prepared. Other experimental methods were same as mentioned above.

\section{Experimental Results}

The results are shown in Table 2. $\mathrm{LD}_{50}$ of the group treated with cortisone alone was $10^{-7.6}$ and that of the non-treated group was 10-6.4. Accordingly, log. difference of the $\mathrm{LD}_{50}$ was 1.2. But the $L D_{50}$ of the other group treated with both cortisone and Milzsin at the same time was $10^{-6.6}$. No significant log. difference of $\mathrm{LD}_{50}$ was observed between this group and the non-treated group. Further, as $\mathrm{LD}_{50}$ of the group treated with Milzsin alone was $10^{-6.3}$, no affection was observed on the susceptibility directly by the treatment with Milzsin. Therefore, it was made clear that the susceptibility increasing effect of cortisone was distinguished by the administration of Milzsin. 
TABLE 2

Effect of Milzsin on the increase of susceptibility by cortisome

\begin{tabular}{|c|c|c|c|c|c|c|}
\hline $\begin{array}{l}\text { No. of } \\
\text { exp. }\end{array}$ & Treatment & $\begin{array}{l}\text { Virus } \\
\text { dilution }\end{array}$ & Result & $\begin{array}{l}\text { Incub. } \\
\text { period }\end{array}$ & $\mathrm{LD}_{50}$ & $\begin{array}{l}\text { Log. } \\
\text { diff. }\end{array}$ \\
\hline 3 & $\begin{array}{l}\text { cortisone } \\
\text { milzsin }\end{array}$ & $\begin{array}{l}10^{-5} \\
10^{-6} \\
01^{-7} \\
10^{-8}\end{array}$ & $\begin{array}{l}5 / 5 \\
5 / 5 \\
1 / 5 \\
0 / 5\end{array}$ & $\begin{array}{l}4.8 \\
6.0 \\
7\end{array}$ & $10^{-66}$ & 0.2 \\
\hline 4 & cortisone & $\begin{array}{l}10^{-5} \\
10^{-6} \\
10^{-7} \\
10^{-8}\end{array}$ & $\begin{array}{l}5 / 5 \\
5 / 5 \\
5 / 5 \\
1 / 4\end{array}$ & $\begin{array}{l}4.5 \\
5.8 \\
6.5 \\
9\end{array}$ & $>10^{-7.6}$ & $>1.2$ \\
\hline 5 & milzsin & $\begin{array}{l}10^{-5} \\
10^{-6} \\
10^{-7} \\
10^{-8}\end{array}$ & $\begin{array}{l}5 / 5 \\
3 / 5 \\
1 / 5 \\
0 / 5\end{array}$ & $\begin{array}{l}5.1 \\
6.0 \\
7\end{array}$ & $10^{-6.3}$ & -0.1 \\
\hline & control & $\begin{array}{l}10^{-5} \\
10^{-6} \\
10^{-7} \\
10^{-8}\end{array}$ & $\begin{array}{l}5 / 5 \\
4 / 5 \\
0 / 5 \\
0 / 5\end{array}$ & $\begin{array}{l}5.3 \\
6.1\end{array}$ & $10^{-6.4}$ & \\
\hline
\end{tabular}

* Harmonic mean of incubation period.

C. Effect of Milzsin on the function of R.E.S.

\section{Materials and Methods}

Mouse: At first, 2 groups were prepared. One of them was administered daily with $1.0 \mathrm{mg}$ of cortisone for 2 days. The other was administered with cortisone as mentioned above and furthermore with Milzsin in a daily dose of $0.2 \mathrm{cc}$ for 3 days intraperitoneally. Other 2 groups were also prepared. In one of these groups Milzsin alone was administered to normal mice and the other group was consisted of non-treated mice. In each group always 3 mice were used as a unit.

Testing Method: Phagocytic function test by india ink granules in subcutaneous tissue cells was adopted for testing the function of R.E.S.. Details of the testing method were described in the previous report (2) and this test was applied to the following similar 2 cases. (a) The above test was applied on the fresh subcutaneous tissue removed from the mice and a comparative observation was carried out. (b) Continuance of the phagocytic function of subcutaneous tissue cells was 
compared in the casewhen mice were killed and carcass kept at $37 \mathrm{C}$. Decision of these results was conducted similarly to the previous experimental method, but the grade of the hyperfunction induced by the administration of Milzsin, when large amounts of histiocytic cells which showed a distinct phagocytic function were observed, was showed as (冊) in the figure.

\section{Experimental Results}

The resuts are shown in Fig. 1. Disturbance of the phagocytic function of

Figure 1.

Effect of Milzsin on the phagocytic function.

(in case of the carcass kept in $37 \mathrm{C}$ )

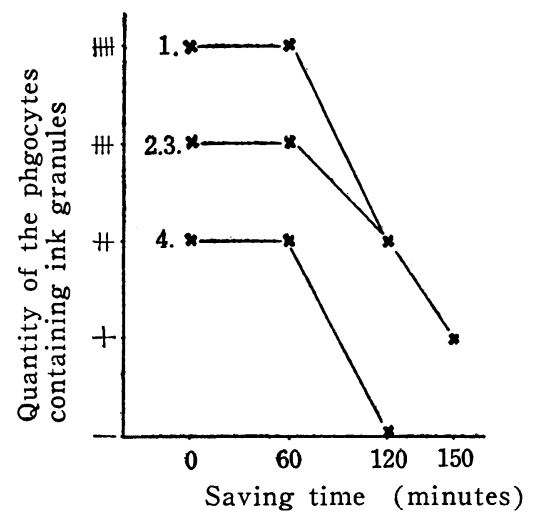

$1 \cdots$ treated group with Milzsin

$2 \cdots$ control group

$3 \cdots$ treated group with cortisone and Milzsin

4 ...treated group with cortisone
R.E.S. caused by the adminstration of cortisone was protected by the injection of Milzsin and continuance of the phagocytic function was also protected. Phagocytic function of mice treated with cortisone disappeared 120 minutes after the administration of cortisone while that of the group treated with both cortisone and Milzsin was still visible even after 150 minutes as same as that of the non-treated group. It was confirmed that the administration of Milzsin alone increased the phagocytic function but its effect was not clearly observed 120 minutes after keeping at $37 \mathrm{C}$ compared with that of the non-treated group.

\section{Protective effect of Milzsin on the lethal effect of cortisone.}

\section{Materials and Methods}

Administration of cortisone: Cortisone was intramuscularly administered daily $2 \mathrm{mg}$ for 2 days. This dose of cortisone is minimum lethal dose which is capable to kill mice of 3 or 4 week-old to about $100 \%$.

Administration of Milzsin: Soon after the first administration of cortisone, Milzsin was adminstered daily $0.2 \mathrm{cc}$ for 4 days and one day respectively. Thus, two methods of adminstration were conducted.

Observation: 2 group administered with both cortisone and Milzsin as men- 
tioned above, a group administered with saline solution and a non-treated group without cortisone were prepared and each group consisted of 15 mice were observed respectively. Furthermore, spleens and livers from mice killed by the administration of cortisone and from those survived by the administration of Milzsin were examined pathohistologically. To serve for the judgement, a group of mice administered with Milzsin for 4 days was prepared and these mice were killed 7 days after the first administration of Milzsin. Thus, anatomic changes were observed macroscopically and especially spleen, liver and kidney were observed histologically.

\section{Experimental Results}

Mortality of the group to which cortisone and saline solution were both administered was $86.6 \%$. Mortality of the treated group to which Milzsin was injected only one time and that of the non-treated group without cortisone were both $93.3 \%$. Namely, significant effect could not be confirmed among these experimental groups but mortality of the treated group to which Milzsin was administered 4 times was $26 \%$ and 11 of the 15 mice were survived. As these results are shown in Table 3, Milzsin can protect the mice from the lethal effect of cortisone. Macroscopic changes of the mice killed by the administration of cortison were significant atrophy of spleen, connective tissue and lymph nodes in whole body. Spleen which shows atrophy and livers from these mice were examined histologically. It was made cleare that significant follicle atrophy was observed in the spleen as shown in the photograph in the previous report (2) and atrophy, significant fatty degeneration and heterogous cells etc. were observed in the liver as shown in Photo. 1. On the other hand, in the mice survived by the administration

TABLE 3

Protective effect of Milzsin on the administration of lethal dose of cortisone

\begin{tabular}{|c|c|c|c|c|c|c|c|c|c|c|c|c|}
\hline \multirow{2}{*}{$\begin{array}{l}\text { No. of } \\
\text { exp. }\end{array}$} & \multirow{2}{*}{ Treatment } & \multicolumn{10}{|c|}{ Days after injection } & \multirow{2}{*}{$\begin{array}{l}\text { Mor- } \\
\text { tality }\end{array}$} \\
\hline & & 1 & 2 & 3 & 4 & 5 & 6 & 7 & 8 & 9 & 10 & \\
\hline 1 & milzsin 1 time & $0^{*}$ & 0 & 0 & 2 & 6 & 9 & 12 & 14 & 14 & 14 & $\begin{array}{r}\% \\
93.3\end{array}$ \\
\hline 2 & milzsin 4 times & $0^{*}$ & $0^{*}$ & $0^{*}$ & $2^{*}$ & 2 & 4 & 4 & 4 & 4 & 4 & $26^{\%}$ \\
\hline 3 & saline solution & $0^{*}$ & $0^{*}$ & $0^{*}$ & $2^{*}$ & 7 & 9 & 13 & 13 & 13 & 13 & $\begin{array}{r}\% \\
86.6\end{array}$ \\
\hline 4 & untreated & 0 & 0 & 0 & 2 & 7 & 9 & 14 & 14 & 14 & 14 & $\begin{array}{r}\% \\
93.3\end{array}$ \\
\hline
\end{tabular}


of Milzsin, pathological finding of the liver as mentioned above could not be observed and follicle atrophy of the spleen was observed only a little or not at all. Concerning the mice administerd with Milzsin alone firstly significant enlargement of spleen was observed macroscopically and enlargement of lymph nodes in whole body was clear. Enlarged spleens weighed 1.5 or 2 times as much compared with those of normal mice and enlargement and multiplication of lymph follicle and multiplication of reticulocytes were observed histologically as shown in Photo. 2. On the contrary, special finding could not be observed in liver and kidney.

\section{E. Relation between cortisone and Milzsin on the activation by vitamin $C$ to enzymic system.}

\section{Materials and Methods}

Mouse and treatment: 3 groups consisted of 12 mice were prepared, namely a control group of normal mice, a group of mice to which cortisone was administered daily $1.0 \mathrm{mg}$ for 2 days, and another group of mice to which Milzsin was administered daily $0.2 \mathrm{cc}$ for 3 days intraperitoneally in combination with the treatment of cortisone. Then, vitamin $\mathrm{C}$ was injected subcutaneouly 4 days after the first treatment of cortisone. 2.5 hours and 5 hours after the injection of vitamin $\mathrm{C}$, 4 mice of each group were killed respectively by means of venesection and their brains were harvested. Then, acitvity of alkaline phosphatase in brain tissue was examined.

Staining method of alkaline phosphatase: After fixing in cold aceton, paraffin sections were made and stained according to Gomori's method slightly modified Namely, (a) kept in a citrate buffer solution ( $\mathrm{pH} 4.5-5.0$ ) for 15 minutes, (b) treated in Gomori's basal solution (ph 9.4) for 2 hours at $37 \mathrm{C}$, (c) kept in a $5 \%$ silver nitrate solution under the direct sun shin for 20 or 30 minutes, (d) fixed for several minutes in a $5 \%$ sodium sulflic acid solution, and then (e) microscopy.

Most optimum operating time in Gomori's basal solution was 3 or 4 hours and good result was obtained. However, at this experiment the grade of activity of enzyme was observed with a grade of stainability after 2 hours. Furthermore, series of these preparates were prepared carefully so as to maintain in the same condition as possible to neglect the non-specific agents.

\section{Experimental Results}

By the stain of alkaline phosphatase in the brain, pericapillaries and a part of meninges were stained into yellow-brown as positive. The stainability was judged 
as slight positive $(t)$, middle positive (H), and strick positive (H) according to its degree. As the results of each group shown in Fig. 2, the administration of vitamin $\mathrm{C}$ under this condition activated temporally the activity of alkaline phosphatase in the brain tissue while the mice treated with cortisone only did not show any activation. But the mice, which were administered with cortisone and Milzsin, showed activation of alkaline phosphatase in their brain tissue as same as normal mice. Although physiological meaning of alkaline phosphatase are still not clear, it is thought that it has a relation to fundamental meta-

Figure 2.

Relation between cortisone and Milzsin upon the activating effect of vitamin $\mathrm{C}$ on the enzymic system.

bolism. Further, restrain of alkaine phosphatase by cortisone alone was not clear as Williams et al (4) had reported about alkaline phosphatase in epiphyse and metaphyse. In this experiment, alkaline phosphatase choiced as a index for resolving the relation between cortisone and Milzsin upon the enzymic system. But these results will not explain the relation between alkaline phosphatase and vita$\min \mathrm{C}$ as a whole.

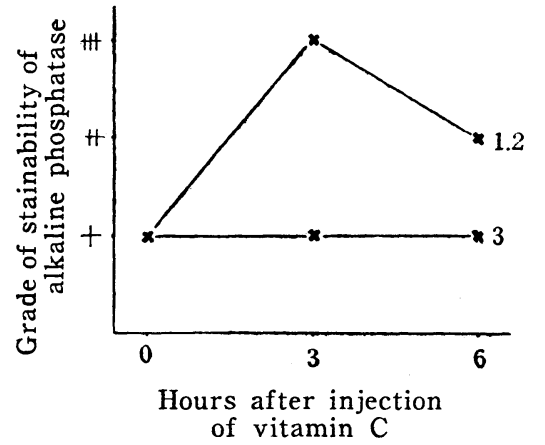

$1 \cdots$ normal mice

$2 \cdots$ treated group with cortisone and Milzsin

$3 \cdots$ treated group with cortisone alone

\section{F. Effect of Milzsin on the anti-inflammatory effect of cortisone.}

\section{Materials and Methods}

Mouse and preliminary treatment: 3 groups in which each consisted of 5 mice were prepared. The 1st group of mice was administered with cortisone daily $0.5 \mathrm{mg}$ for 3 days. 2nd group of mice was administered with cortisone as mentioned above and with Milzsin daily $0.2 \mathrm{cc}$ for 3 days intraperitoneally. The other group was a control group in which mice were not treated. The hair on the back of these mice was trimmed by scissors and eva cream (depilatory) was coated and a depilated space of about $1 \mathrm{~cm}$ square was made.

Observation: Air pouch was made in the subcutaneous region of depilated space by injecting $0.3 \mathrm{cc}$ of air and $0.05 \mathrm{cc}$ of sterilized turpentine oil was injected into the air pouch. The course of a non-infectious inflammation caused by this agents was observed. 


\section{Experimental Results}

The results are shown in Table 4. The control group without any administration of cortisone showed a remarkable inflammatory response 2 days after the injection of turpentine oil. At the site of injection redness was observed macroscopically, exsudate was deposited, and suppration was caused. A crust was formed after 8 or 9 days. On the contrary, the mice treated with cortisone showed a delayed appearance of inflammatory response 2 to 4 days longer than the former, and its process also remarkably delayed. But in the mice treated with Milzsin and cortisone could be observed an almost similar appearance and a course of the inflammation same as in non-treated mice. Series of inflammatory reaction process were demonstrated by photograph in the previous report.

TABLE 4

Effects of cortisone and Milzsin on the course of inflammation by turpentine oil

\begin{tabular}{|c|c|c|c|c|c|c|c|c|c|c|}
\hline \multirow{2}{*}{$\frac{\text { Treatment }}{\text { cortisone }}$} & \multicolumn{5}{|c|}{$\begin{array}{l}\text { Days to } \\
\text { inflammatory response }\end{array}$} & \multicolumn{5}{|c|}{$\begin{array}{l}\text { Days to } \\
\text { crust formation }\end{array}$} \\
\hline & 4 & 4 & 5 & 5 & 5 & 14 & 14 & 15 & 15 & 16 \\
\hline $\begin{array}{l}\text { cortisone } \\
\text { milzsin }\end{array}$ & 2 & 2 & 3 & 3 & 3 & 9 & 9 & 9 & 9 & 10 \\
\hline control & 2 & 2 & 2 & 2 & 2 & 8 & 8 & 8 & 9 & 9 \\
\hline
\end{tabular}

G. On the proliferation promoting effect of Milzsin to fibroblasts.

\section{Materials and Methods}

Tissue: Minced 9 days old whole chick embryo tissue was employed.

Culture media: As a culture medium of chick embryo tissue Simms' 7-2-1 solution was employed. This medium consisted of 7 parts of Simms' X 7 solution, 2 parts of $50 \%$ chick embryo extract and one part of fowl serum. Another medium contained no embryo extract, which acted as a growth promoting factor for fibroblasts, was also used. Furthermore, 2 media, in which Milzsin was added in the concentration of $3 \%$ to the 2 media described above, were prepared. Thus, 4 kinds of culture media were used for the examination.

Experimental methods: By conducting the tissue culture employing the materials above mentioned, the proliferation promoting effect of Milzsin was examined. 
About 10 pieces of tissue fixed by fowl plasma in test tube, and $2 \mathrm{cc}$ of cultuer media were added to each tube and they were cultured by the roller-tube method at $37 \mathrm{C}$. Proliferation of fibroblasts was observed microscopically daily and the change of $\mathrm{pH}$ of medium was also observed as a reference. Details of the method were followed to the description of Feller (5).

\section{Expcrimental Results}

The results are shown in Fig. 3. Proliferation of fibroblasts was so slow in the culture media without embryo extract, while in those added with Milzsin instead of embryo extract proliferation was as remarkable as in those with embryo extract. In the culture media to which both Milzsin and embryo extract were added, proliferation of fibroblasts was excellently remarkable. Then, it was confirmed that Milzsin had a remarkable promoting effect of proliferation on connective tissues.
Figure 3.

Effect of Milzsin on the proliferation of fibroblasts.

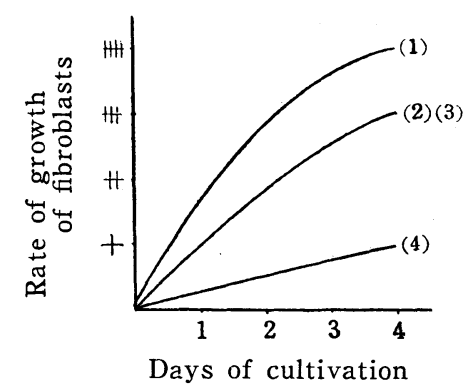

Original cult. fulid: Simms' 7-2-1 solution

(1) ..original + Milzsin

(2) $\cdots$ original

(3) - original - chick emb. ext. + Milzsin

(4) -.original - chick emb. ext.

H. On the susceptibility of mice blockaded R.E.S. With ink granules.

\section{Materials and Mcthods}

Preparation of india ink solution: An ink-stick was rubbed in an Akama ink-slabe with Ringer solution. An about $5 \%$ india ink solution was prepared, then sterilized and filtered.

Method of blockade: 2 group of the experimental animals were prepared. One of them consisted of mice which were injected with the india ink solution intraperitoneally daily $0.2 \mathrm{cc}$ for 4 days. The other consisted of mice which were similarly but only once was injected with $0.2 \mathrm{cc}$ of the india ink solution. Then, grade of the blockade of R.E.S. was presumed from Komagi's experimental results.

Method of inoculation of virus and the observation: Serial 10-fold dilution of the virus suspension were inoculated into those blockaded mice and by the values of $L D_{j 0}$ the effect of blockade was judged. 


\section{Experimental Results}

The results are shown in Table $5 . \quad L_{50}$ of the groups treated with india ink solution 4 times and one time, were $10^{-6.8}$ and $10^{-64}$ respectively and that of the control group was $10^{-6.2}$. Then, log. difference of the $\mathrm{LD}_{; 0}$ of above the 2 groups, with that of the control group, were 0.6 and 0.2 . From the results thus obtained the effect of the blockade of R.E.S. was not clearly observed.

TABLE 5.

Effect of the blockade of R.E. system on the susceptibility

\begin{tabular}{|c|c|c|c|c|c|c|}
\hline $\begin{array}{l}\text { No. of } \\
\text { exp. }\end{array}$ & Treatment & $\begin{array}{l}\text { Virus } \\
\text { dilution }\end{array}$ & Result & $\begin{array}{l}\text { Incub. } \\
\text { period }\end{array}$ & $\mathrm{LD}_{50}$ & $\begin{array}{l}\text { Log. } \\
\text { diff. }\end{array}$ \\
\hline 6 & $\begin{array}{l}\text { India ink } \\
3 \text { times } \\
\text { before inocul. }\end{array}$ & $\begin{array}{l}10^{-5} \\
10^{-6} \\
10^{-7} \\
10^{-8}\end{array}$ & $\begin{array}{l}5 / 5 \\
4 / 4 \\
2 / 5 \\
0 / 5\end{array}$ & $\begin{array}{l}4.8 \\
5.6 \\
6.8\end{array}$ & $10^{-6.8}$ & 0.6 \\
\hline 7 & $\begin{array}{l}\text { India ink } \\
1 \text { time } \\
\text { before inocul. }\end{array}$ & $\begin{array}{l}10^{-5} \\
10^{-6} \\
10^{-7} \\
10^{-8}\end{array}$ & $\begin{array}{l}5 / 5 \\
4 / 5 \\
0 / 5 \\
0 / 5\end{array}$ & $\begin{array}{l}5.3 \\
5.9\end{array}$ & $10^{-6.4}$ & 0.2 \\
\hline & control & $\begin{array}{l}10^{-5} \\
10^{-6} \\
10^{-7} \\
10^{-8}\end{array}$ & $\begin{array}{l}5 / 5 \\
3 / 5 \\
0 / 5 \\
0 / 5\end{array}$ & $\begin{array}{l}5.3 \\
6.1\end{array}$ & $10^{-6.2}$ & \\
\hline
\end{tabular}

* Harmonic mean of incubation period.

\section{Effect of cortisone on the tissue culture of virus.}

\section{Materials and Methods}

Tissue: Brains of 1 or 2 days old mice were used.

Culture medium: Simms' X 7 solution same as mentioned above was employed.

Cortisone and its administration: (a) Cortone acetate (Merck) for clinical use suspended in saline solution was used. Cortone acetate was solved in $95 \%$ ethanol to $2 \mathrm{mg} / \mathrm{cc}$ and was added to the culture media in the rate of $30 \mathrm{r} / \mathrm{cc}$ and $10 \mathrm{r} / \mathrm{cc}$ respectively. (b) Crystalline cortisone (free alcohol)* for experimental use was used. That was added to culture fluid in the rate of $250 \mathrm{r} / \mathrm{cc}$ and $100 \mathrm{r} / \mathrm{cc}$.

* This cortisone was kindly supplied by Dr. Knoppers of Merck INC. New York, U.S.A.. 
Method of cultivation: Suspended tissue culture was conducted in 25 cc Erlenmyer flasks. The method was refered to Pearson's experiment (6). Firstly, mouse brain minced and small pieces of tissue were distributed in 3 flasks. And then, infected mouse brain emulsion were added to the culture fluid, to which cortisone (clinical use) was added in the rate mentioned above, in the final concentration of $10^{-5}$. $3 \mathrm{cc}$ of these culture fluids were respectively divided into 3 flasks of each group. Furthermore, the experiment on crystalline cortisone was conducted by the same method. 2nd day and 4th day of cultivation, tissues were collected from 3 flasks of each group and $10 \%$ emulsion was prepared by grinding in the tube specially designed for small amounts. The rate of multiplication of virus was observed by $\mathrm{LD}_{50}$.

\section{Experimental Results}

(a) As shown in Table 6, the addition of cortisone (clinical use) in the rate of $30 \mathrm{r} / \mathrm{cc}$ and $10 \mathrm{r} / \mathrm{cc}$ did not affect the rate of the multiplication of virus. $\mathrm{LD}_{50}$ of these experimental group after cultivation of 2 days were $10^{-2.2}$ and $10^{-2.4}$, while that of these groups after cultivation of 4 days were $10^{-6.3}$ and $10^{-6.0}$. On the other hand, $\mathrm{LD}_{50}$ of the control group were $10^{-2.4}$ and $10^{-6.2}$ after cultivation of 2 days and 4 days respectively. Then difference of the results of these groups could not be observed and it was confirmed that the concentration of $1.5 \%$ of ethanol did not also affect clearly the multiplication of virus.

TABLE 6

Effect of cortisone on the multiplication of the virus in tissue culture (1)

\begin{tabular}{|c|c|c|}
\hline $\begin{array}{l}\text { Culture days } \\
\text { Simms' } \times 7 \text { solut. }\end{array}$ & 2 & 4 \\
\hline$\stackrel{*}{\text { cortisone }} 30 \gamma / \mathrm{cc}$ & $10^{-2.2}$ & $10^{-6.3}$ \\
\hline cortisone $10 \mathrm{r} / \mathrm{cc}$ & $10^{-2.4}$ & $10^{-6.0}$ \\
\hline ethanol $\quad 1.5 \%$ & $10^{-2.5}$ & $10^{-6.2}$ \\
\hline control & $10^{-2.4}$ & $10^{-6.2}$ \\
\hline $\begin{array}{l}\text { * cortisone for clir } \\
\text { in ethanol }(2 \mathrm{mg} \\
\text { initial virus cono }\end{array}$ & 1 use & olved \\
\hline
\end{tabular}

\section{TABLE 7}

Effect of cortisone on the multiplication of the virus in tissue culture (2)

\begin{tabular}{c|c|c}
\hline $\begin{array}{c}\text { Culture days } \\
\text { to }\end{array}$ & 2 & 4 \\
\hline $\begin{array}{c}* \\
\text { cortisms' } \times 7 \text { solut. } 250 \gamma / \mathrm{cc}\end{array}$ & $10^{-2.6}$ & $10^{-6.0}$ \\
\hline cortisone $100 \gamma / \mathrm{cc}$ & $10^{-2.3}$ & $10^{-6.3}$ \\
\hline control & $10^{-2.6}$ & $10^{-6.3}$ \\
\hline
\end{tabular}

* crystalline cortisone for experimental use initial virus concentration $\cdots 10^{-5}$ 
(b) Relative large dose of crystalline cortisone, in case of adding cortisone in the rate of $250 \mathrm{r} / \mathrm{cc}$ and $100 \mathrm{r} / \mathrm{cc}$, did not also affect the multiplication of virus similarly to the above results. These results are shown in Table 7 .

\section{DISCUSSION}

It was still not clear whether the susceptibility increasing effect of cortisone on the experimental animals was a direct action or not. The present authors had questions how much the hypofunction of R.E.S. following the atrophy of spleen was effective as the action of cortisone or further how its secondary influence was distinguished from the general action of cortisone. For resolving these doubts, firstly the effect of the emulsion of mouse spleen treated at low temperature on the susceptibility was examined and no effect was observed. But we found the Milzsin which is a protein-free derivate** extracted from bovine spleen at low temperature by looking for the concentrated derivate of spleen component with interest to the experimental results by Cole et al (3); namely spleen emulsion affected to the effect of X-ray irradiation. By using Milzsin in this experiment, the authors confirmed that the susceptibility increasing effect of cortisone was extinguished by its administration but Milzsin itself did not directly influence on virus. Thus, Milzsin protected the action of cortisone on the host, accordingly, the effect of cortisone seemed to be a secondary influence based on the deficiency of effective factors of Milzsin. By conducting the experiment concerning that the Milzsin would make an influence on the hypofunction of R.E.S. caused by the administration of cortisone, it was made clear that Milzsin increased the function of R.E.S. and protected the hypofunction of it caused by the administration of cortisone. Furthermore, Milzsin protected not only the life of mice from the administration of lethal dose of cortisone, which seems to explain satisfactory the effect of cortisone, but also histological changes. When we think of the susceptibility to virus, the points mentioned previously, it should be thought of the relation to the enzymic system in living body as the most fundamental meaning. Previouly, Kiyoshi (8) had reported that spleen and R.E.S. are indispensable in the course of action of the substance which influenced on oxidation-reduction system and pointed out a part of physiological meaning of R.E.S. that had a correlation with enzymic actions in living body. We made clear that cortisone and Milzsin have a cor-

** Jacobson (7) had reported that spleen emulsion without cellular component could not be protected the injury of $\mathrm{X}$-ray irradiation but $\mathrm{I}$ think that it will be controlled by the amount of effective factors. 
relation with enzymic actions in ovo by use the same method of Kiyoshi's experiment. Therefore, this fact was understood as a possible mechanism that cortisone influenced on the state of virus susceptible cells. Furthermore, Milzsin distinguished the anti-inflammatory effect of cortisone and it had a remarkable action of proliferating fibroblasts against cortisone.

The reason why no remarkable influence is observed after the removal of spleen having such important factors will be explained by the fact that the remaining R.E.S. compensates the function of spleen. We think that the splenic hormone*** which is an effective factor of Milzsin should be recognized as a R.E.S. hormone. For explaining the mechanism of the inner secretory protection, it will be necessary to point out the similarities of pathological findings induced by R.E.S. and the effect of cortisone as an evidence of the facts mentioned above. It will be explained by the description of predecessors. Firstly, on the metabolism of protein, cortisone hinders the course of synthesis of protein from amino acids, namely, it is thought that cortisone acts antianabolic (there are some authors saying that cortisone acts catabolic). R.E.S. influences on the metabolism of protein and it is thought that oxydative deamination of amino acid is conducted by R.E.S.. Further, it is well known that R.E.S. rules the metabolism of carbohydrate and fat. Recently, Yamagata (9) has reported the importance of R.E.S. to the sugar metabolism. Hyperglycemia caused by the splenectomy and the blockade of R.E.S., many kinds of lipoidosis thought to be caused by the disturbance of the metabolism of lipoid are also observed similarly when cortisone is employed. They are hyperglycemia, fattness and distribution anomaly of fat. Furthermore, there will be a correlation between the increase of the amounts of $\mathrm{Ca}$ in blood induced by blockade of R.E S. and the abrasion of $\mathrm{Ca}$ from born induced by cortisone. More, the decreasing of the antibody-formation and hindering of the allergy are similarly observed. Then, as far as the mechanism of action of cortisone is explained, these points can not be neglected as an accidental agreement. Further consideration is nescessary to explain if all of the actions of cortisone will be illustrated by this mechanism. But the existence of the chain of hormone between adrenocortex and R.E.S. should be added to pituitary-adrenocortical system concerning the inner secretory protecting mechanism and infection. Selye's stress concept (10) (11) suggested many interesting problems will be developed to a more wider and more suitable concept by

*k* Concerning this problem, a theroretical large spot will be that the deficiency symptom of splenic hormone can not cleary observed; in other words, it is impossible undertake a compensatory experiment. And it is very doubtful, when think of the producting cells, that there are 2 contradictory factors in spleen. 
the adding of these findings. It is very interesting that the enlargement of spleen and the increasing of the function of R.E.S. are caused by DOCA.

Then, most basic reaction system against infection cannot happen to exist separately against bacteria and virus, and the speciality to virus should be considered on duty and expression of that. Thus, it is understood that the function of R.E.S. plays an important role in ruling the susceptibility to virus, while a similar effect was not observed even if the blockade of R.E.S. was conducted. But this would be caused by incomplete method of blockade by intraperitoneal injection of india ink compared with the administration of cortisone which is considered uniquely. This problem should be investigated on the blockade method. Concerning the effect of cortisone in vitro, influence of cortisone on the propagation of virus in tissue culture was observed but the multiplication of virus was not affected by the addition of cortisone. Robbins et al (12) have also reported that cortisone by use of tissue culture did not affect the multiplication of virus. On the other hand, Kilbourn et al (13) have reported that cortisone promoted the multiplication of virus. We have never doubted about the experimentai result like this, but we think that this result should be considered separately from the concept of adrenocortex hormone. As mentioned above, bold discussion and opinion are explained, but remaining problems still unknown will be investigated in the future.

As last, the variation of receptivity which rules the complete multiplication of virus, especially the change of the state of susceptible cells responsible to cause the disease is important as a initial factor to rule the susceptibility of virus, particularly the clinical infection by neurotrophic virus and the role of R.E.S. responsible to this agent should be stressed.

When think about inapparent infection, this problem will be understood rationally if the factors, the growth cycle of virus and the location of the multiplication of virus, will be further investigated.

\section{SUMMARY}

In the previous report, the mechanism of the action of cortisone that could increase the susceptibility of mice to virus was partially explained, and it was made clear in more detail in this report. We had some questions how much the hypofunction of reticuloendothelial system following the atrophy of spleen is effective as the action of cortisone or further how its secondary influence is distinguished from the general action of cortisone.

These questions have been resolved as follows. 
1) Milzsin extracted as splenic hormone, can extinguish the susceptibility increasing effect of cortisone, but has not a direct influence on virus. Accordingly the ffect of cortisone seems to have a secondary influence based on the deficiency of splenic hormone.

2) Milzsin enhances the function of R.E.S. and induces the enlargements of spleen and lymph tissuses. The enlargement of follicles and the proliferation of reticulocytes are observed histologically in the enlarged spleen.

3) Furthermore, it is made clear that the splenic hormone has a close relation to the enzymic action in ovo. This fact is understood as the mechanism that has influence on the metabolic system of virus suscptible cells.

4) Milzsin not only protects mice from the lethal effect of cortisone (M.L.D.) but also suppresses their histological changes.

5) Milzsin extinguishes the anti-inflammatory action of cortisone, and it has a remarkable action of proliferating fibroblasts against cortisone.

6) Although the effect of cortisone on the virus is studied in tissue culture, it is not simple and direct action of cortisone.

The reason why no remarkable influence is observed after the removal of spleen having such important factors will be explained by the fact that the remaining R.E.S. compensates the function of spleen. The pathological findings of R.E.S. are very similar to the wide effects including the metabolic effect of cortisone.

The splenic hormone should be recognized as R.E.S. hormone and the existence of the chain of hormone between adrenocortex and R.E.S. should be added to pituitary-adrenocortical system which constitutes the foundation of inner secretory protecting mechanism. Further consideration is, of course, nescessary if all of the action of cortisone will be illustrated by this mechanism.

The variation of the receptibity which rules the multiplication of virus, particularly the change of the state of susceptible cells responsible to cause the disease are important as a initial factor to rule the susceptibility of the virus, particularly the clinical infection by neurotropic virus and the role of R.E.S. responsible to this agent should be stressed.

\section{REFERENCES}

1. KANDA, Y.: Studies on the influence upon the susceptibility of mice to virus I Report. VIRUS, Vol. 5, 36-41, 1955. (in Japanese)

2. Nakagawa, Y. AND Kanda, Y.: Studies on the influence upon the susceptibility of mice to virus II Report. Kurume Medical Journal, Vol. 2, 1-18, 1955. 
Photo. 1.

Microscopic change in the liver when M. L. D. of cortisone is administered.

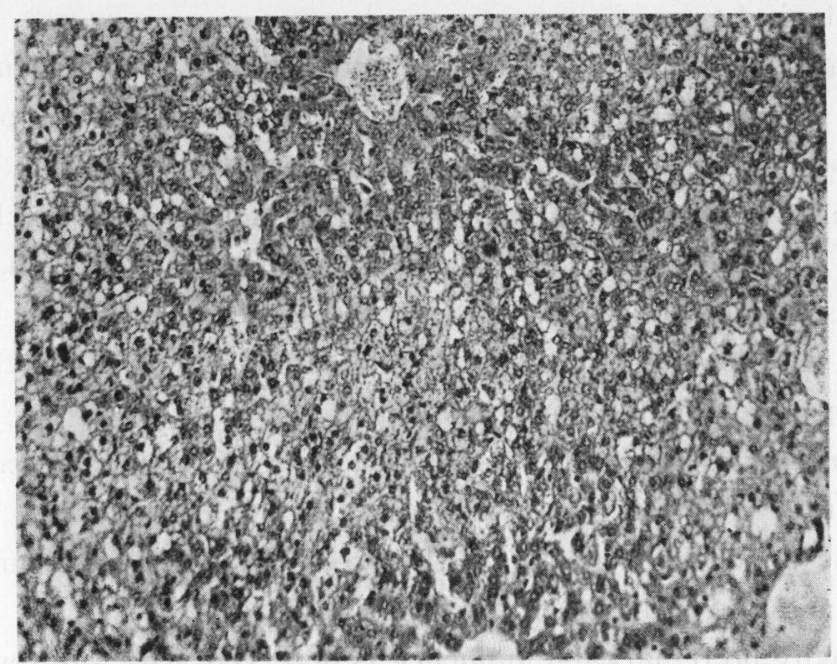

$(\times 154)$

Photo. 2.

Microscopic change in the spleen when Milzsin is administered.

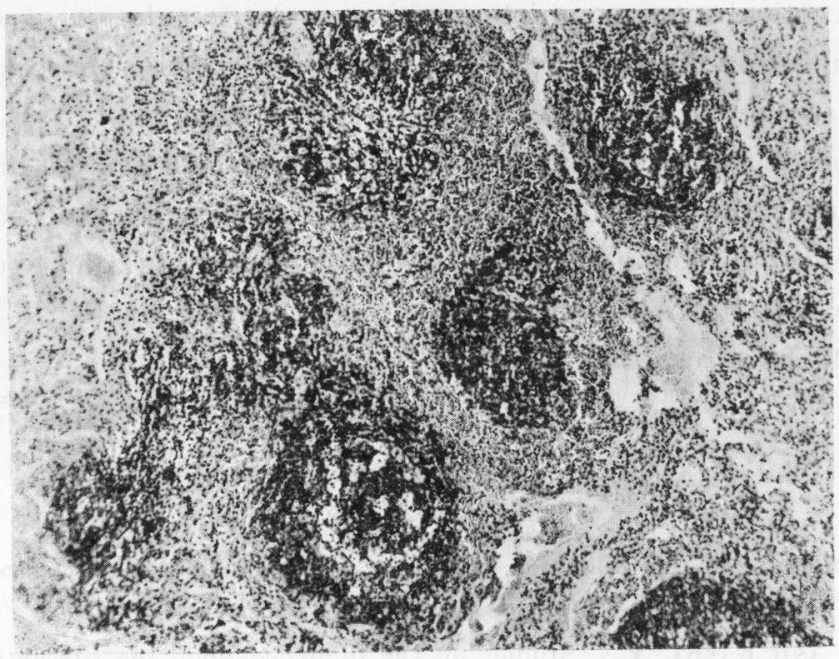

$(\times 77)$ 
KANDA, Y.: VIRUS, Vol. 5, 179-188, 1955. (in Japanese).

3. Cole, L. J., Fishler, M. C., Erlis, M. E. ANd Bond, V. P.: Protection of mice against Xirradiation by spleen homogenates administered after exposure. Proc. Soc. Exp. Biol. and Med., Vol. 80, 112-117, 1952.

4. Williams, H. L. and Watson, E. M.: Influence of hormones upon phosphatase content of rat femurs. Endocrinology, Vol. 29, 250, 1941.

5. Feller, A. E.: Technich and application of roller tube culture. Handbuch der Virusforshung, 1, 1950, Wien Springer-Verlag.

6. Pearson, H. E.: Factors affecting the propagation of Theiler's GD VII mouse encephalomyelitis virus in tissue culture. J. Immunol., Vol. 64, 447-454, 1950.

7. JACoBson, L. O.: Modification of radium injury in experimental animals. Am. J. Roent. and Rad. Therap., Vol. 72, 543-555, 1954.

8. Kiroshi, Y.: On the special function of spleen. Jap. Jour. Surgery., Vol. 49, 100-126, 1948. (in Japanese).

9. Yamagata, S.: R.E.S. and sugar metabolism. Saishinigaku, No. 12, 1952. (in Japanese).

10. Selye, H.: 1st annual report of stress. Acta Montreal, 1951.

11. Selye, H.: The story of the adaptation syndrome. Acta Montreal, 1952,

Jap. Trans., Ishiyaku, Tokyo, 1953.

12. Robrins, F. C., Weller, T. H. and Enders, J. F.: Studies on the cultivation of poliomyelitis virus in tissue culture, II. J. Iumunol., Vol. 69, 673-694, 1952.

13. Kilbourne, E. D. and Tateno, I.: In vitro effects of cortisone on multiplication of influenza B virus. Proc. Soc. Exp. Biol. and Med., Vol. 82, 274-277, 1953. 